Prepared in cooperation with the U.S. Army Corps of Engineers, Metropolitan St. Louis Sewer District, Missouri Department of Transportation, Missouri American Water, Federal Emergency Management Agency Region 7, the city of Pacific, the city of Eureka, the city of Wildwood, and the city of Arnold

\title{
Flood-Inundation Maps of the Meramec River from Eureka to Arnold, Missouri, 2018
}

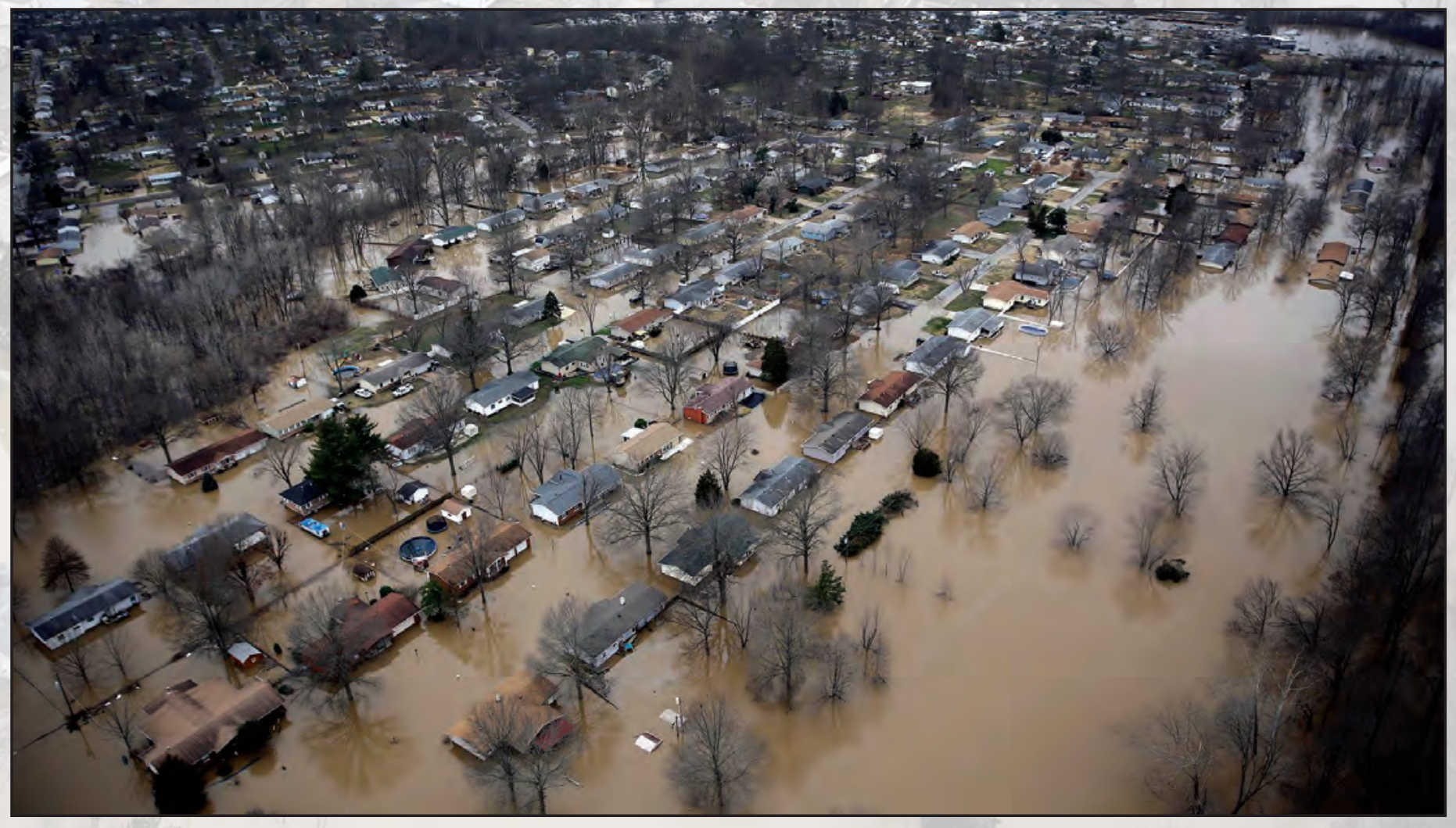

Scientific Investigations Report 2019-5004 
Cover. Photograph showing Meramec River flooding taken in Arnold, Missouri. Photograph taken December 31, 2015, by David Carson, St. Louis Post-Dispatch, used with permission. 


\section{Flood-Inundation Maps of the Meramec River from Eureka to Arnold, Missouri, 2018}

By Benjamin J. Dietsch and Kellan R. Strauch

Prepared in cooperation with the U.S. Army Corps of Engineers, Metropolitan St. Louis Sewer District, Missouri Department of Transportation, Missouri American Water, Federal Emergency Management Agency Region 7, the city of Pacific, the city of Eureka, the city of Wildwood, and the city of Arnold

Scientific Investigations Report 2019-5004 


\title{
U.S. Department of the Interior \\ DAVID BERNHARDT, Acting Secretary
}

\author{
U.S. Geological Survey \\ James F. Reilly II, Director
}

U.S. Geological Survey, Reston, Virginia: 2019

For more information on the USGS - the Federal source for science about the Earth, its natural and living resources, natural hazards, and the environment-visit https://www.usgs.gov or call 1-888-ASK-USGS.

For an overview of USGS information products, including maps, imagery, and publications,

visit https://store.usgs.gov.

Any use of trade, firm, or product names is for descriptive purposes only and does not imply endorsement by the U.S. Government.

Although this information product, for the most part, is in the public domain, it also may contain copyrighted materials as noted in the text. Permission to reproduce copyrighted items must be secured from the copyright owner.

Suggested citation:

Dietsch, B.J., and Strauch, K.R., 2019, Flood-inundation maps of the Meramec River from Eureka to Arnold, Missouri, 2018: U.S. Geological Survey Scientific Investigations Report 2019-5004, 12 p., https://doi.org/10.3133/sir20195004.

ISSN 2328-0328 (online) 


\section{Acknowledgments}

The authors wish to thank the U.S. Army Corps of Engineers St. Louis District and the Metropolitan St. Louis Sewer District for funding the operation and maintenance of the streamgages used for this study. Special thanks are given to the National Weather Service for their continued support of the U.S. Geological Survey flood-inundation mapping program. 



\section{Contents}

Acknowledgments ……...................................................................................................................

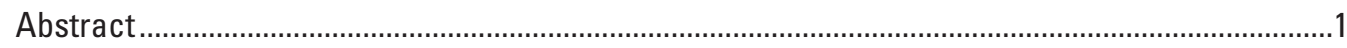

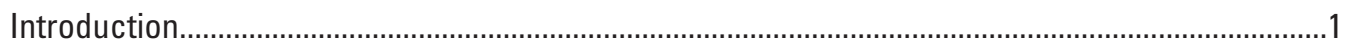

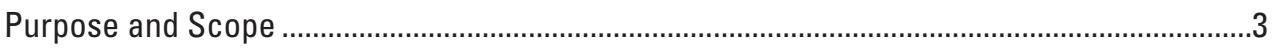

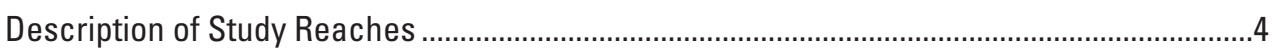

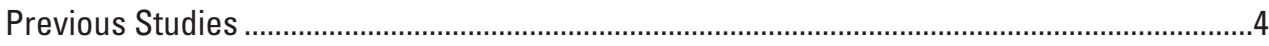

Creation of Flood-Inundation Map Library …….......................................................................

Computation of Water-Surface Profiles..............................................................................

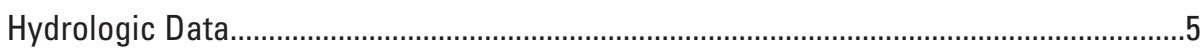

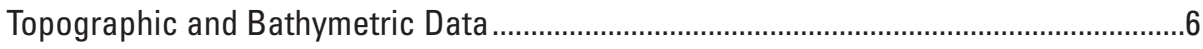

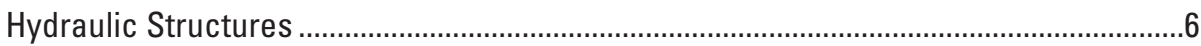

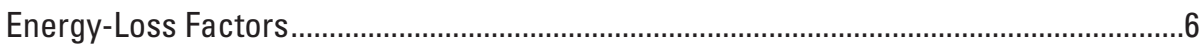

Hydraulic Model................................................................................................................

Development of Water-Surface Profiles .............................................................................

Development of Flood-Inundation Maps ............................................................................

Flood-Inundation Map Delivery ...................................................................................

Disclaimer for Flood-Inundation Maps ........................................................................10

Uncertainties and Limitations Regarding Use of Flood-Inundation Maps ......................10

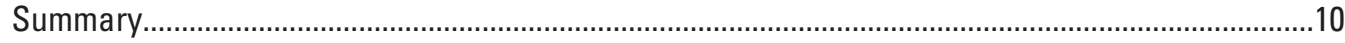

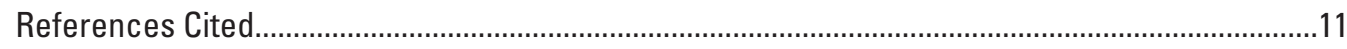

\section{Figures}

1. Map showing location of the Meramec River from Eureka to Arnold, Missouri, and locations of the cooperative U.S. Geological Survey streamgages along the lower Meramec River

2 Graph showing comparison of hydraulic-model output and high-water mark elevations for a major flood event on December 2015-January 2016, Meramec River, Missouri.

\section{Tables}

1. Information for U.S. Geological Survey streamgages along or near the Meramec River study reach

2. Peak discharges for selected annual exceedance probabilities for Meramec River near Eureka, Missouri....

3. Estimated water-surface elevation at the confluence of the Meramec and Mississippi Rivers for selected stages at U.S. Geological Survey streamgage 070100000 Mississippi River at St. Louis, Missouri...

4 Stage and water-surface elevations simulated at reference streamgages used in study... 


\section{Conversion Factors}

U.S. customary units to International System of Units

\begin{tabular}{|c|c|c|}
\hline Multiply & By & To obtain \\
\hline \multicolumn{3}{|c|}{ Length } \\
\hline foot $(\mathrm{ft})$ & 0.3048 & meter $(\mathrm{m})$ \\
\hline foot $(\mathrm{ft})$ & 30.48 & centimeter $(\mathrm{cm})$ \\
\hline mile (mi) & 1.609 & kilometer (km) \\
\hline \multicolumn{3}{|c|}{ Area } \\
\hline square mile $\left(\mathrm{mi}^{2}\right)$ & 2.590 & square kilometer $\left(\mathrm{km}^{2}\right)$ \\
\hline \multicolumn{3}{|c|}{ Flow rate } \\
\hline cubic foot per second $\left(\mathrm{ft}^{3} / \mathrm{s}\right)$ & 0.02832 & cubic meter per second $\left(\mathrm{m}^{3} / \mathrm{s}\right)$ \\
\hline
\end{tabular}

Vertical coordinate information is referenced to (1) stage, the height above an arbitrary datum established at a streamgage, and (2) elevation, the height above the North American Vertical Datum of 1988 (NAVD 88).

Horizontal coordinate information is referenced to the North American Datum of 1983 (NAD 83).

\section{Abbreviations}

AHPS

DEM

FIS

GIS

HEC-GeoRAS

HEC-RAS

lidar

NWS

USGS
Advanced Hydrologic Prediction Service

digital elevation model

flood insurance study

geographic information system

U.S. Army Corps of Engineers Hydrologic Engineering Centers Geospatial River Analysis System

U.S. Army Corps of Engineers Hydrologic Engineering Centers River Analysis System

light detection and ranging

National Weather Service

U.S. Geological Survey 


\title{
Flood-Inundation Maps of the Meramec River from Eureka to Arnold, Missouri, 2018
}

\author{
By Benjamin J. Dietsch and Kellan R. Strauch
}

\section{Abstract}

Libraries of digital flood-inundation maps that spanned a combined 37.2-mile reach of the Meramec River that extended upstream from Eureka, Missouri, to downstream near the confluence of the Meramec and Mississippi Rivers were created by the U.S. Geological Survey (USGS) in cooperation with the U.S. Army Corps of Engineers, Metropolitan St. Louis Sewer District, Missouri Department of Transportation, Missouri American Water, Federal Emergency Management Agency Region 7, and the cities of Pacific, Eureka, Wildwood, and Arnold. The flood-inundation maps, which can be accessed through the USGS Flood Inundation Mapping Science website at https://water.usgs.gov/osw/flood_inundation/, depict estimates of the areal extent and depth of flooding corresponding to selected water levels (stages) at the cooperative USGS streamgages for the Meramec River near Eureka, Mo. (USGS station 07019000), the Meramec River at Valley Park, Mo. (USGS station 07019130), the Meramec River at Fenton, Mo. (USGS station 07019210), and the Meramec River at Arnold, Mo. (USGS station 07019300). Near-real-time stage data at these streamgages may be obtained from the USGS National Water Information System at https://doi.org/10.5066/ F7P55KJN or the National Weather Service (NWS) Advanced Hydrologic Prediction Service at https://water.weather. gov/ahps/, which also forecasts flood hydrographs at these sites (listed as NWS sites erkm7, vllm7, fnnm7, and arnm7, respectively).

Flood profiles were computed for the stream reach by means of a calibrated one-dimensional step-backwater hydraulic model. The model was calibrated using a stage-discharge relation at the Meramec River near Eureka, Mo., streamgage (USGS station 07019000) and documented high-water marks from the flood of December 2015 through January 2016.

The calibrated hydraulic model was used to compute water-surface profiles: 1 set for the Meramec River near Eureka, Mo., streamgage (USGS station 07019000); 1 set for the Meramec River at Valley Park, Mo., streamgage (USGS station 07019130); 7 sets for the Meramec River at Fenton, Mo., streamgage (USGS station 07019210) for a range of Mississippi River conditions; and 8 sets for the Meramec River at Arnold, Mo., streamgage (USGS station 07019300) for a range of Mississippi River conditions. The water-surface profiles were produced for stages at 1-foot (ft) intervals referenced to the datum from each streamgage and ranging from the NWS action stage, or near bankfull discharge, to the stage corresponding to the estimated 0.2-percent annual exceedance probability (500-year recurrence interval) flood, as determined at the Meramec River near Eureka, Mo., streamgage (USGS station 07019000). The simulated water-surface profiles then were combined with a geographic information system digital elevation model (derived from light detection and ranging data having a 0.28 -ft vertical accuracy and 3.28-ft horizontal resolution) to delineate the area flooded at each simulated $1-\mathrm{ft}$ stage increment. Previously published flood-inundation maps were updated and incorporated in the flood map libraries for USGS stations 07019130 and 07019210 to complete the map sets corresponding to eight Mississippi River conditions.

The availability of these maps, along with internet information regarding current stage from the USGS streamgages and forecasted high-flow stages from the NWS, will provide emergency management personnel and residents with information that is critical for flood response activities such as evacuations and road closures and for postflood recovery efforts.

\section{Introduction}

The cities of Eureka, Valley Park, Fenton, and Arnold, Missouri, along the lower Meramec River (fig. 1) in southern St. Louis County and Jefferson County, have estimated populations of 10,$189 ; 6,942 ; 4,022$; and 20,808 , respectively (U.S. Census Bureau, 2010). The Meramec River is one of the longest free-flowing rivers in Missouri, and its flood plain has numerous developed areas along the downstream part of the basin in St. Louis County (Missouri Department of Natural Resources, 2015). The Meramec River near Eureka, Valley Park, Fenton, and Arnold has severely flooded numerous times, most recently in 1982, 2008, 2015, and 2017. The highest observed flood at the cooperative U.S. Geological Survey (USGS) streamgage on the Meramec River near Eureka, Mo. (USGS station 07019000), was recorded in May 2017 at a stage of 46.11 feet (ft; National Weather Service, 2018a). The highest observed flood at the cooperative USGS streamgage on the Meramec River at Valley Park, Mo. 


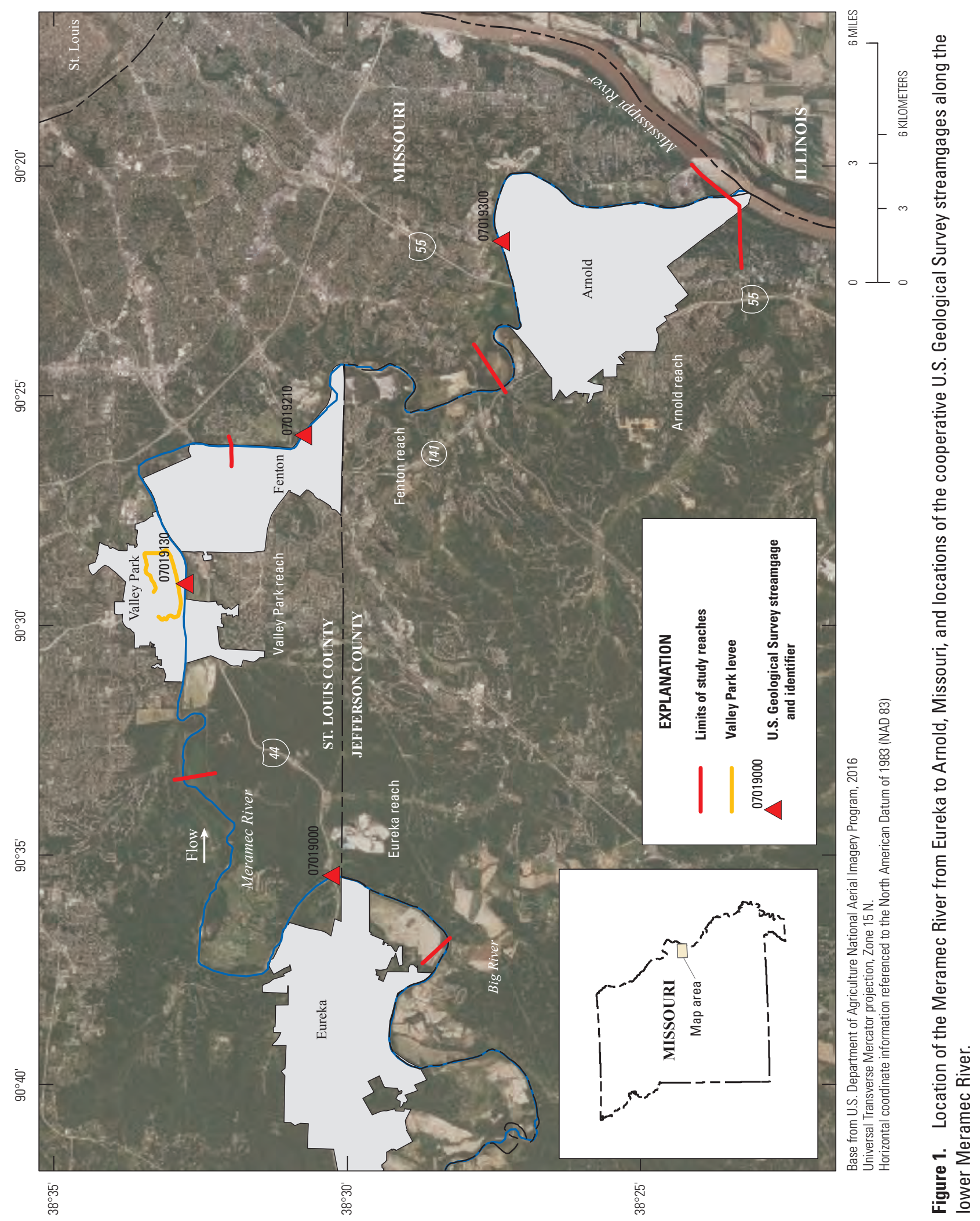


(USGS station 07019130), was recorded in December 2015 at a stage of $44.11 \mathrm{ft}$ (National Weather Service, 2018a). The December 2015 flood also resulted in the highest observed stage at the Meramec River at Fenton, Mo., streamgage (USGS station 07019210; $42.86 \mathrm{ft}$ ) and the Meramec River at Arnold, Mo., streamgage (USGS station 07019300; $47.26 \mathrm{ft}$ ). The flooding during December 2015 through January 2016 and in May 2017 affected many commercial and residential areas, water supply and treatment facilities, and transportation infrastructure along the lower Meramec River.

Before this study, emergency responders in St. Louis and Jefferson Counties (fig. 1) relied on several information sources to make decisions on how to best alert the public and mitigate flood damages. One source is the Federal Emergency Management Agency flood insurance studies (more commonly known as FISs) for St. Louis County (Federal Emergency Management Agency, 2015). A second source of information is the USGS streamgage data (available at https://www.usgs. gov/centers/cm-water) from which current (2018) or historical water levels (stages) and discharges (flows), including annual peak flows, can be obtained (U.S. Geological Survey, 2017b). A third source of flood-related information is the National Weather Service (NWS) Advanced Hydrologic Prediction Service (AHPS), which provides measured stage data and issues forecasts of stage for the cooperative USGS streamgages on the Meramec River near Eureka, Mo. (USGS station 07019000); the Meramec River at Valley Park, Mo. (USGS station 07019130); the Meramec River at Fenton, Mo. (USGS station 07019210); and the Meramec River at Arnold, Mo. (USGS station 07019300; National Weather Service, 2018a).

Although the current stage at a USGS streamgage is particularly useful for residents near a streamgage, it is of little use to residents farther upstream or downstream because the watersurface elevation is not constant along the entire stream reach and because water level at a streamgage is difficult to translate into depth and areal extent of flooding at points distant from the streamgage. One way to address these informational gaps is to produce a library of flood-inundation maps that are referenced to the stages recorded at the USGS streamgage. By referring to the appropriate map, emergency responders can discern the severity of flooding (depth of water and areal extent), identify roads that are or will soon be flooded, and make plans for notifying or evacuating residents in harm's way for some distance upstream and downstream from the streamgage. In addition, the capability to visualize the potential extent of flooding may motivate residents to take precautions and heed warnings that they previously might have disregarded. In 2016-18, the USGS, in cooperation with the U.S. Army Corps of Engineers, St. Louis Metropolitan Sewer District, Missouri Department of Transportation, Missouri American Water, Federal Emergency Management Agency Region 7, and the cities of Pacific, Eureka, Wildwood, and Arnold completed a project to produce a library of flood-inundation maps for four sections of the lower Meramec River upstream from Eureka, Mo., to near the mouth of the Meramec River at the Mississippi River (fig. 1).

\section{Purpose and Scope}

This report describes the development of a series of estimated flood-inundation maps for a 37.2-mile (mi) reach of the Meramec River from upstream near the confluence of the Meramec River and the Big River to downstream near the confluence of the Meramec River and the Mississippi River, and the report identifies where on the internet the maps can be viewed and ancillary data (geographic information system [GIS] flood polygons and depth grids) can be downloaded. The flood-inundation maps cover a 37.2-mi reach of the lower Meramec River 3.0 mi upstream from the streamgage for the Meramec River near Eureka, Mo. (USGS station 07019000), to near the mouth of the Meramec River (fig. 1). The maps were produced for water levels referenced to the stages recorded at the cooperative USGS streamgages: the Meramec River near Eureka, Mo. (USGS station 07019000); the Meramec River at Valley Park, Mo. (USGS station 07019130); the Meramec River at Fenton, Mo. (USGS station 07019210); and the Meramec River at Arnold (USGS station 07019300), Mo. (fig. 1 and table 1). The 11.0-mi section of the Meramec River 3 mi upstream from the streamgage near Eureka, Mo., to $8 \mathrm{mi}$ downstream from the streamgage near Eureka, Mo., is associated with the Meramec River near Eureka, Mo., streamgage and is herein referred to as the "Eureka reach." The 9.1-mi section of the Meramec River 4.9 mi upstream from the Meramec River at Valley Park, Mo., streamgage to $4.2 \mathrm{mi}$ downstream from the Meramec River at Valley Park, Mo., streamgage is associated with the Meramec River at Valley Park streamgage and is herein referred to as the "Valley Park reach." The 7.6-mi section of Meramec River 1.7 mi upstream from the Meramec River at Fenton, Mo., streamgage to $5.9 \mathrm{mi}$ downstream from the Meramec River at Fenton, Mo., streamgage is associated with the Meramec River at Fenton, Mo., streamgage and is herein referred to as the "Fenton reach." The 9.5-mi section of Meramec River 3.2 mi upstream from the Meramec River at Arnold, Mo., streamgage to the mouth of the Meramec River is associated with the Meramec River at Arnold, Mo., streamgage and is herein referred to as the "Arnold reach." The map libraries for stations 07019210 and 07019300 are composed of watersurface profiles for combinations of 1-ft stage intervals at the streamgage and 8 maps corresponding to 8 Mississippi River conditions, 1 set associated with near median stage conditions and 7 sets associated with elevated stage conditions on the Mississippi River, were produced to complete the map libraries. The maps cover ranges in stage from 17 to $55 \mathrm{ft}$, referenced to the streamgage datum at the Meramec River near Eureka, Mo. (USGS station 07019000); from 12 to $54 \mathrm{ft}$, referenced to the streamgage datum at the Meramec River at Valley Park, Mo. (USGS station 07019130); from 22 to $50 \mathrm{ft}$, referenced to the streamgage datum at the Meramec River at Fenton, Mo. (USGS station 07019210); and from 25 to $51 \mathrm{ft}$, referenced to the streamgage datum at the Meramec River at Arnold, Mo. (USGS station 07019300). The 17-ft stage at station 07019000 , the 11-ft stage at station 07019130 (previously 
Table 1. Information for U.S. Geological Survey streamgages along or near the Meramec River study reach.

[Station location is shown in figure 1. NAD 83, North American Datum of 1983; NAVD 88, North American Vertical Datum of 1988; Mo., Missouri; ${ }^{\circ}$, degrees; ', minutes; ", seconds]

\begin{tabular}{|c|c|c|c|c|c|c|c|c|}
\hline Station name & $\begin{array}{l}\text { Station } \\
\text { number }\end{array}$ & $\begin{array}{l}\text { Drainage } \\
\text { area, } \\
\text { in square } \\
\text { miles }\end{array}$ & $\begin{array}{l}\text { Latitude } \\
\text { (NAD 83) }\end{array}$ & $\begin{array}{l}\text { Longitude } \\
\text { (NAD 83) }\end{array}$ & $\begin{array}{l}\text { Local } \\
\text { datum, } \\
\text { in feet } \\
\text { above } \\
\text { NAVD } 88\end{array}$ & $\begin{array}{l}\text { Period of } \\
\text { record }\end{array}$ & $\begin{array}{l}\text { Maximum recorded } \\
\text { stage, in feet } \\
\text { (elevation, NAVD } \\
\text { 88), and date of } \\
\text { maximum stage }\end{array}$ & $\begin{array}{l}\text { Maximum discharge, } \\
\text { in cubic feet per } \\
\text { second, and date of } \\
\text { maximum discharge }\end{array}$ \\
\hline $\begin{array}{l}\text { Mississippi } \\
\text { River at } \\
\text { St. Louis, } \\
\text { Mo. }\end{array}$ & 07010000 & 697,000 & $38^{\circ} 37^{\prime} 44^{\prime \prime}$ & $90^{\circ} 10^{\prime} 47^{\prime \prime}$ & 379.58 & 1861-present & $\begin{array}{c}49.58 \\
(429.16) \\
\text { August } 1,1993\end{array}$ & $\begin{array}{c}1,080,000 ; \\
\text { August } 1,1993\end{array}$ \\
\hline $\begin{array}{l}\text { Meramec } \\
\text { River near } \\
\text { Eureka, } \\
\text { Mo. }\end{array}$ & 07019000 & 3,788 & $38^{\circ} 30^{\prime} 17^{\prime \prime}$ & $90^{\circ} 35^{\prime} 27^{\prime \prime}$ & 403.84 & $\begin{array}{c}\text { 1904, 1905, } \\
\text { 1915, 1916, } \\
\text { 1922-present }\end{array}$ & $\begin{array}{c}46.11 \\
(449.95) \\
\text { May 3, 2017 }\end{array}$ & $\begin{array}{c}169,000 \\
\text { May } 3,2017\end{array}$ \\
\hline $\begin{array}{l}\text { Meramec } \\
\text { River at } \\
\text { Valley } \\
\text { Park, Mo. }\end{array}$ & 07019130 & 3,850 & $38^{\circ} 32^{\prime} 48^{\prime \prime}$ & $90^{\circ} 29^{\prime} 06^{\prime \prime}$ & 391.22 & $\begin{array}{l}\text { 1915-present } \\
\text { (stage only) }\end{array}$ & $\begin{array}{c}44.11 \\
(435.33) \\
\text { December } 31,2015\end{array}$ & Not available \\
\hline $\begin{array}{l}\text { Meramec } \\
\text { River at } \\
\text { Arnold, } \\
\text { Mo. }\end{array}$ & 07019300 & 3,950 & $38^{\circ} 27^{\prime} 24^{\prime \prime}$ & $90^{\circ} 21^{\prime} 38^{\prime \prime}$ & 372.58 & $\begin{array}{c}1973, \\
\text { 1979-present } \\
\text { (stage only) }\end{array}$ & $\begin{array}{c}47.26 \\
(419.84) \\
\text { December } 31,2015\end{array}$ & Not available \\
\hline
\end{tabular}

mapped by Dietsch and Sappington, 2017), the 22-ft stage at station 07019210 , and the 22 -ft stage at station 07019300 are stages defined by the NWS as the "action stage" or that stage that, when reached by a rising stream, requires the NWS or a partner to take some type of mitigation action in preparation for possible substantial hydrologic activity (National Weather Service, 2018b). The maximum stage at each streamgage for the estimated flood-inundation maps exceeds the "major flood stage" as defined by the NWS ( $31 \mathrm{ft}$ at station $07019000,25 \mathrm{ft}$ at station 07019130, $32 \mathrm{ft}$ at station 07019210 , and $38 \mathrm{ft}$ at station 07019300), exceeds the maximum recorded stage at the streamgages, and is the stage that corresponds to a flow rate of about 227,000 cubic feet per second $\left(\mathrm{ft}^{3} / \mathrm{s}\right)$ at the cooperative USGS streamgage for the Meramec River near Eureka, Mo. (USGS station 07019000), which is the estimated 0.2-percent annual exceedance probability (500-year recurrence interval) flood (Holmes and others, 2016).

\section{Description of Study Reaches}

The Meramec River Basin in eastern Missouri primarily is in the Ozark Highlands ecoregion (Omernik, 1987). The basin terrain is characterized by gently rolling to moderately hilly topography. The drainage areas of streamgages within the study reach range from about 3,788 square miles $\left(\mathrm{mi}^{2}\right)$ at the Meramec River near Eureka, Mo., streamgage, near the upstream study limit, to about 3,950 $\mathrm{mi}^{2}$ at the Meramec River at Arnold, Mo., streamgage near the downstream study limit. No large tributaries join the Meramec River within the study reach, although several small tributaries with drainage areas less than $25 \mathrm{mi}^{2}$ enter the Meramec River along the reach. The total study reach is about $37.2 \mathrm{mi}$ long $(11.0 \mathrm{mi}$ for the Eureka reach, $9.1 \mathrm{mi}$ for the Valley Park reach, $7.6 \mathrm{mi}$ for the Fenton reach, and $9.5 \mathrm{mi}$ for the Arnold reach) and has an average top-of-bank channel width of about $320 \mathrm{ft}$ and an average channel slope of $1.6 \mathrm{ft}$ per mile. Most of the land contiguous to the study reach is urban or developed. The main channel within the study reach has 18 road crossings or other structures (railroad, roadway, and pedestrian bridges) as of February 2017. Levee-protected areas are behind the Valley Park levee system (fig. 1). The levee-protected areas are included in the U.S. Army Corps of Engineers National Levee Database (U.S. Army Corps of Engineers, 2017).

\section{Previous Studies}

The current FIS for St. Louis County, Mo., and incorporated areas (Federal Emergency Management Agency, 2015) 
was last revised by Missouri State Emergency Management Agency and AMEC Earth \& Environmental, Inc., in 2015.

A USGS report examining characteristics of flooding in the Meramec River Basin in December 2015-January 2016 presents estimates of the peak discharges with 2-, 1-, and 0.2-percent annual exceedance probabilities for the Meramec River near Eureka, Mo. (table 2; Holmes and others, 2016). The estimated annual exceedance probability corresponding to the December 2015 flood at the Meramec River near Eureka, Mo., streamgage was 1.1 percent, with a 66.7-percent confidence interval for the true annual exceedance probability of the flood extending from 0.7 to 3.2 percent. The observed peak discharge of $162,000 \mathrm{ft}^{3} / \mathrm{s}$ for the December 2015 flood falls within the estimated 2-percent annual exceedance flow of $140,000 \mathrm{ft}^{3} / \mathrm{s}$ and the estimated 1-percent annual exceedance flow of $165,000 \mathrm{ft}^{3} / \mathrm{s}$ based on 99 years of peak record used in the analysis (Holmes and others, 2016). The estimated flood discharges and their corresponding stages at the Meramec River near Eureka, Mo., streamgage were used in the determination of the range of simulated flows in the development of the flood-inundation maps for the Meramec River at Valley Park, Mo.; the Meramec River at Fenton, Mo.; and the Meramec River at Arnold, Mo., streamgages because no discharge data were available for these streamgages.

Flood-inundation maps were produced for the sections of the Valley Park reach and the Fenton reach in 2017 (Dietsch and Sappington, 2017). The maps produced for the 2017 report represent conditions in which the Mississippi River was assumed to be at or near a stage corresponding to median annual flow. Under the scenario represented by the maps, the effect of backwater condition imposed by the Mississippi River on the mapped sections was assumed to be minimal.

\section{Creation of Flood-Inundation Map Library}

The USGS has standardized the procedures for creating flood-inundation maps for flood-prone communities (U.S. Geological Survey, 2017a) so that the process followed and products produced are similar regardless of the USGS office that is responsible for the work. Tasks specific to developing the flood maps for the Meramec River near Eureka, at Valley Park, at Fenton, and at Arnold, Mo., were (1) acquiring the hydraulic model that was developed by the U.S. Army Corps of Engineers St. Louis District (U.S. Army Corps of Engineers, written commun., 2016); (2) analyzing the flow and stage data collected at 5 streamgages, 4 on the Meramec River and 1 on the Mississippi River; (3) refining energy-loss factors (roughness coefficients) in the stream channel and flood plain by calibration; (4) computing water-surface profiles using the U.S. Army Corps of Engineers Hydrologic Engineering Centers River Analysis System (HEC-RAS) computer program (Brunner, 2016); (5) producing estimated flood-inundation maps at several stream stages for four reaches using the U.S. Army Corps of Engineers Hydrologic Engineering Centers Geospatial River Analysis System (HEC-GeoRAS) computer program (Ackerman, 2009) and the ArcMap application of ArcGIS (Esri, 2017); and (6) preparing the maps, as shapefile polygons that depict the areal extent of flood inundation and as depth grids that provide the depth of floodwaters, using GIS for display on a USGS flood-inundation mapping application.

\section{Computation of Water-Surface Profiles}

The water-surface profiles used to produce the 660 floodinundation maps in this study were computed using HECRAS, version 5.0.3 (Brunner, 2016). The HEC-RAS model is a one-dimensional step-backwater hydraulic model that simulates water-surface profiles with unsteady-state flow computation options. The simulation reach started near the confluence with the Big River (about 3.0 mi upstream from the cooperative USGS streamgage for the Meramec River near Eureka, Mo.), and extended $37.2 \mathrm{mi}$ downstream to near the mouth of the Meramec River (fig. 1).

\section{Hydrologic Data}

During the flood of December 2015, the study reaches included 1 stage-discharge streamgage (station 07019000) and 2 stage-only streamgages (stations 07019130 and 07019300). Soon after, in January 2016, station 07019210 was installed on the Meramec River at Fenton, Mo. (fig. 1; table 1). Stage is measured every 15 minutes at stations 07019000, 07019130, and 07019300 and every 5 minutes at station 07019210 ; stage is transmitted hourly by a satellite radio in each streamgage; and stage is made available on the internet through the USGS

Table 2. Peak discharges for selected annual exceedance probabilities for Meramec River near Eureka, Missouri.

[Station location is shown in figure 1. USGS, U.S. Geological Survey. Data from Holmes and others, 2016]

$\begin{array}{cc}\text { Location on } & \text { Drainage area, } \\ \text { Meramec River } & \text { in square miles }\end{array}$
Estimated discharge, in cubic feet per second, (for indicated annual exceedance probability, in percent) 
National Water Information System (U.S. Geological Survey, 2017b). Stage data from the streamgages are referenced to a local datum but can be converted to water-surface elevations referenced to the North American Vertical Datum of 1988 (NAVD 88) by adding $403.84 \mathrm{ft}$ for station 07019000 , $391.22 \mathrm{ft}$ for station $07019130,382.76 \mathrm{ft}$ for station 07019210 , and $372.58 \mathrm{ft}$ for station 07019300 (table 1).

Flows ranging from $4,700 \mathrm{ft}^{3} / \mathrm{s}$ to $242,000 \mathrm{ft}^{3} / \mathrm{s}$ were used as input into the hydraulic model to produce water-surface profiles corresponding to selected stages at stations 07019000 , 07019130, 07019210, and 07019300. No large tributaries join the Meramec River within the 37.2-mi simulation reach; therefore, additional discharges were not added for tributary inflows. A hydrograph for the Mississippi River stages at the mouth of the Meramec River was used for the downstream model constraint for model calibration, and stage data collected at the Meramec River at Valley Park, Mo., streamgage were used, in addition to observed high-water marks, for model calibration for the simulation of the December 2015January 2016 flood on the Meramec River.

\section{Topographic and Bathymetric Data}

All topographic data used in this study are referenced vertically to NAVD 88 and horizontally to the North American Datum of 1983. Cross-section elevation data were obtained from a digital elevation model (DEM) that was derived from light detection and ranging (lidar) data that were collected by Surdex Corporation on January 29-30 and February 1, 2012 (Surdex Corporation, 2012a). Postprocessing of these data was completed by Surdex Corporation in April 2012. The original lidar data have a horizontal resolution of $2.8 \mathrm{ft}$ and vertical accuracy of $0.55 \mathrm{ft}$ at a 95 -percent confidence level for the "open terrain" land-cover category (root mean squared error of $0.28 \mathrm{ft}$; Surdex Corporation, 2012b). By these criteria, the lidar data support production of 2-ft contours (Dewberry, 2012); the final DEM, which was resampled to a 3.28-ft grid-cell size, has a vertical accuracy of plus or minus $1 \mathrm{ft}$. Elevation data were extracted from the DEM for 131 cross sections in the modeled reach using HEC-GeoRAS, a set of procedures, tools, and utilities for processing geospatial data in ArcGIS, and, subsequently, were input to the HEC-RAS model. Because lidar data cannot provide ground elevations below the water surface of a stream, channel cross sections were surveyed by Hanson Professional Engineering Services, on contract for the U.S. Army Corps of Engineers St. Louis District, during 2015 (U.S. Army Corps of Engineers, written commun., 2016). Cross-sectional depths were measured using hydroacoustic instrumentation at 86 locations within the simulation reach.

Where possible, DEM-generated cross sections were made to coincide with the locations of the within-channel fieldsurveyed cross sections by directly merging within-channel field-surveyed data with the DEM data for these cross sections. For all other cross sections, the within-channel data were estimated by interpolation from the closest field-surveyed cross section data.

\section{Hydraulic Structures}

A total of 18 structures, consisting of road and railroad crossings, have the potential to affect water-surface elevations during floods along the study reaches (12 total in the simulation reach). Bridge-geometry data were obtained from field surveys completed by Hanson Professional Engineering Services, on contract for the U.S. Army Corps of Engineers St. Louis District (U.S. Army Corps of Engineers, written commun., 2016) and were obtained from the Missouri Department of Transportation (Missouri Department of Transportation, written commun., 2016).

A total of 11 lateral structures were modeled to facilitate the simulation of flow from the main river channel to storage areas. The lateral structures represented the natural ground that separates the main river channel from a storage area such as a lake, tributary flood plain, or low-lying area. Because the lateral flow structures represent an overland flow interface between the river channel and flood plain, weir coefficients of 0.2 were used instead of values typically used for inline weirs (1.0-2.2; King and Brater, 1963).

The community of Valley Park contains a levee that is included in the National Levee Database (U.S. Army Corps of Engineers, 2017). The Valley Park levee system levees about 380 acres on the north bank of the Meramec River. The levee was simulated in the HEC-RAS model as a lateral structure with the area within the levee being represented as a storage area. For inundation mapping purposes, the landward side of the levee is shown as an "area of uncertainty" because there is uncertainty as to how this area would be inundated in the event of the levee overtopping or failing. The calibration run of the hydraulic model for the December 2015 flood indicated that the Valley Park levee was not overtopped during that event, in concordance with observation. The run of the hydraulic model used to create flood-inundation maps indicated that the water surface would exceed the levee for the water-surface profiles corresponding to stages greater than $45 \mathrm{ft}$ (436.22 ft, NAVD 88) at the Meramec River at Valley Park, Mo., streamgage (USGS station 07019130).

\section{Energy-Loss Factors}

Hydraulic analyses require the estimation of energy losses that result from frictional resistance exerted on flow in a channel. These frictional resistance energy losses are quantified by the Manning's roughness coefficient ( $n$ value). Initial (precalibration) Manning's roughness coefficients ( $n$ values) for energy-loss (friction-loss) calculations were estimated by comparing high-resolution aerial photographs and crosssectional views of the Meramec River channel and photographs of channels for which $n$ values have been computed and published in references such as Barnes (1967), Arcement and Schneider (1989), and Coon (1998). The main channel of the Meramec River within the simulation reach consisted of a gravel bed bottom with different amounts of vegetation encroachment from the channel banks. A range in initial $n$ 
values from 0.040 to 0.050 was selected for the main channel. The flood plains have a variety of land-use characteristics in areas adjacent to the Meramec River, and the initial $n$ values ranged from 0.060 to 0.100 for the flood plains.

As part of the calibration process, the initial $n$ values were varied by flow and adjusted until the differences between simulated and observed water-surface elevations at the Meramec River at Valley Park, Mo., streamgage and at high-water marks were minimized. The final $n$ values ranged from 0.030 to 0.040 for the main channel and 0.050 to 0.130 for the floodplain areas modeled in this analysis.

\section{Hydraulic Model}

The HEC-RAS analysis for this study was done using the unsteady-state flow computation option. The unsteady flow computation (as opposed to steady-state) was selected for this hydraulic analysis to capture the flow dynamics throughout the study reach and to generate the inundation maps. The upstream boundary condition for the hydraulic-model calibration was a discharge hydrograph corresponding to the flows observed for the calibration event, the flood of December 28, 2015-January 3, 2016, herein referred to as the "December 2015 flood." Model runs for flood-map production were made with an artificial, rising-leg hydrograph that included flows corresponding to stages that ranged over the stages of interest at $1-\mathrm{ft}$ increments, relative to local streamgage datums, from bankfull to about the 0.2-percent annual exceedance probability flood. The artificial hydrograph used a stair-step technique (flows were increased by small increments over about 3 days to allow the model to stabilize) to cover the range of stages. Flows corresponding to the stages of interest were identified, and the corresponding profiles were used to map the flood plains. A stage hydrograph was computed for the Mississippi River at the mouth of the Meramec River using an adjustment based on a curve fitted to published water surfaces for selected annual exceedance probabilities from the streamgage at the Mississippi River at St. Louis, Mo. (USGS station 07010000), to the mouth of the Meramec River (U.S. Army Corps of Engineers, 2004). The stage hydrograph was used as the downstream boundary condition for the calibration. The stage data at the Meramec River at Valley Park streamgage, about midway along the reach, were used to calibrate the model performance. Unsteady-state flow data consisted of flow regime, boundary conditions, and a hydrograph that corresponded to the December 2015 flood. A subcritical (tranquil) flow regime was assumed for the simulations. The initial conditions for storage areas along the reach were set to closely match the water-surface elevation of the adjacent main channel cross section corresponding to the first simulated discharge.

The HEC-RAS model was calibrated to the current stagedischarge relation at the Meramec River near Eureka, Mo., streamgage and to documented high-water marks surveyed by USGS personnel after the December 2015 flood at 26 locations along the simulation reach and stage data at the Meramec River at Valley Park, Mo., streamgage. The model was calibrated by adjusting Manning's $n$ values and changing the ineffective flow areas until the results of the hydraulic computations closely agreed with the observed water-surface elevations for given flows. The root mean square error computed from the differences between surveyed high-water marks in the simulation reach for the December 2015 flood and simulated peak elevations was $0.47 \mathrm{ft}$. Comparisons of hydraulicmodel output and the stage-discharge rating at the Meramec River near Eureka, Mo., streamgage and of hydraulic-model output and high-water mark elevations (fig. 2) demonstrate that the model is capable of simulating accurate water levels for the extent of the simulation reach.

\section{Development of Water-Surface Profiles}

The flood-inundation profiles for the Valley Park and Fenton reaches generated in Dietsch and Sappington (2017) were simulated with a downstream boundary condition corresponding to a Mississippi River stage at or near median flow and, therefore, assumed no substantial backwater effect from the Mississippi River. For this report, additional unsteady hydraulic-modeling simulations were run using the calibrated model and constant Mississippi River water-surface elevations to determine the effects of elevated Mississippi River conditions on the lower Meramec River. The results of hydraulicmodeling simulations indicated that backwater effects from the Mississippi River extended upstream through the Arnold and Fenton reaches; therefore, eight Mississippi River conditions were selected to serve as downstream boundary conditions for hydraulic-modeling simulations. The conditions used for the hydraulic simulations included 1 scenario in which the Mississippi River was assumed to be at or near the stage corresponding to the median annual flow and 7 scenarios in which the Mississippi River stage was assumed to be near "action stage" (28 ft) or higher as defined by the NWS at the Mississippi River at St. Louis, Mo., streamgage (USGS station 07010000). Because the Mississippi River at St. Louis, Mo., streamgage is about 8.9 mi upstream from its confluence with the Meramec River, water-surface elevation at the Mississippi River at St. Louis, Mo., streamgage was not used directly as the downstream boundary water surface for each hydraulicmodeling simulation. Instead, a curve was fit to the results of the frequency analysis study (U.S. Army Corps of Engineers, 2004) to estimate the water-surface elevation at the confluence of the Meramec and Mississippi Rivers for the stages at the Mississippi River at St. Louis, Mo., streamgage corresponding to the eight downstream boundary conditions (table 3 ).

The calibrated hydraulic model was used to generate a total of 411 water-surface profiles (table 4). The hydraulic model was used to generate water-surface profiles for one set of stages for the Eureka and Valley Park reaches. The hydraulic model was used to generate water-surface profiles for one set of stages for each Mississippi River condition (stage equivalent to $26 \mathrm{ft}, 30 \mathrm{ft}, 34 \mathrm{ft}, 38 \mathrm{ft}, 42 \mathrm{ft}, 46 \mathrm{ft}$, and $50 \mathrm{ft}$ at the Mississippi River at St. Louis, Mo., streamgage [USGS station 07010000]) for the Fenton and Arnold reaches. 


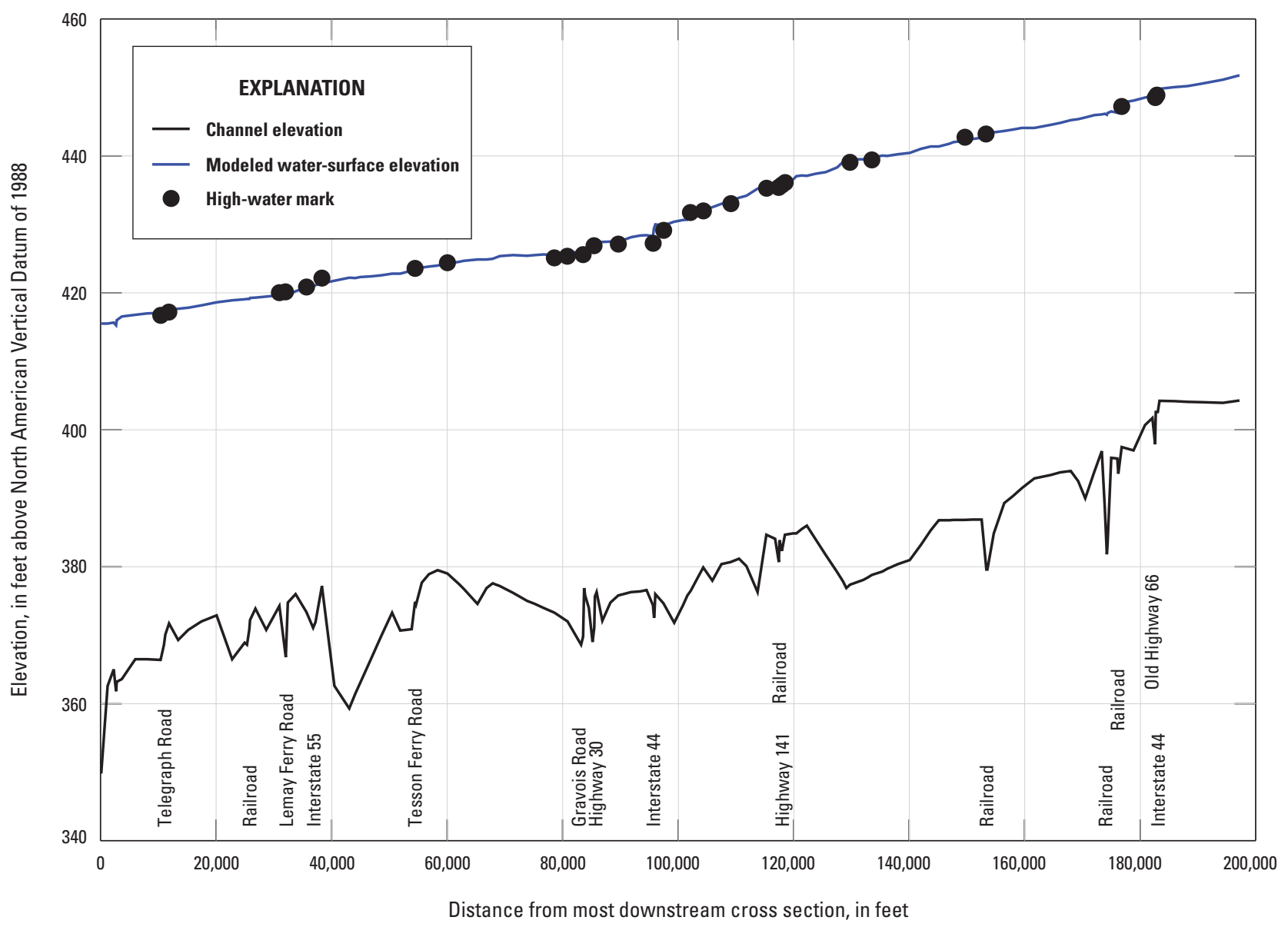

Figure 2. Comparison of hydraulic-model output and high-water mark elevations for a major flood event on December 2015January 2016, Meramec River, Missouri.

Table 3. Estimated water-surface elevation at the confluence of the Meramec and Mississippi Rivers for selected stages at U.S. Geological Survey streamgage 070100000 Mississippi River at St. Louis, Missouri.

[Station location is shown in figure 1. NAVD 88, North American Vertical Datum of 1988]

\begin{tabular}{cc}
\hline $\begin{array}{c}\text { Stage at } \\
\text { Mississippi River at } \\
\text { St. Louis, Missouri } \\
\text { (07010000), in feet } \\
\text { (elevation, NAVD 88) }\end{array}$ & $\begin{array}{c}\text { Estimated water-surface elevation } \\
\text { of Mississippi River at } \\
\text { confluence with Meramec River, } \\
\text { in feet above NAVD 88 }\end{array}$ \\
\hline $14(393.6)$ & 382.5 \\
$26(405.6)$ & 394.5 \\
$30(409.6)$ & 398.3 \\
$34(413.6)$ & 402.1 \\
$38(417.6)$ & 406.2 \\
$42(421.6)$ & 410.4 \\
$46(425.6)$ & 414.7 \\
$50(429.6)$ & 417.5 \\
\hline
\end{tabular}

Additionally, water-surface profiles were generated for the Arnold reach with the Mississippi River near median flow conditions (stage equivalent to $14 \mathrm{ft}$ at USGS station 07010000). Water-surface profiles were generated for a total of 39 stages at 1-ft intervals between $17 \mathrm{ft}$ and $55 \mathrm{ft}$ for the Eureka reach (which included USGS station 07019000) as referenced to the local streamgage datum, and these stages correspond to elevations of $420.84 \mathrm{ft}$ and $458.84 \mathrm{ft}$ above NAVD 88, respectively. Water-surface profiles were generated by Dietsch and Sappington (2017) for a total of 44 stages at 1 - $\mathrm{ft}$ intervals between $11 \mathrm{ft}$ and $54 \mathrm{ft}$ for the Valley Park reach (which included USGS station 07019130) as referenced to the local streamgage datum, and these stages correspond to elevations of $402.1 \mathrm{ft}$ and $445.1 \mathrm{ft}$ above NAVD 88, respectively. Water-surface profiles were generated for Mississippi River condition stage equivalents of $26 \mathrm{ft}, 30 \mathrm{ft}, 34 \mathrm{ft}, 38 \mathrm{ft}, 42 \mathrm{ft}$, $46 \mathrm{ft}$, and $50 \mathrm{ft}$ and used with water-surface profiles generated by Dietsch and Sappington (2017), which corresponded to the Mississippi River condition stage equivalent of $14 \mathrm{ft}$, for a total of 192 Mississippi River conditions and stages at 1 - $\mathrm{ft}$ intervals ranging from $22 \mathrm{ft}$ to $51 \mathrm{ft}$ as referenced to the local streamgage datum for the Fenton reach (which includes USGS station 07019210), and these stages correspond to 


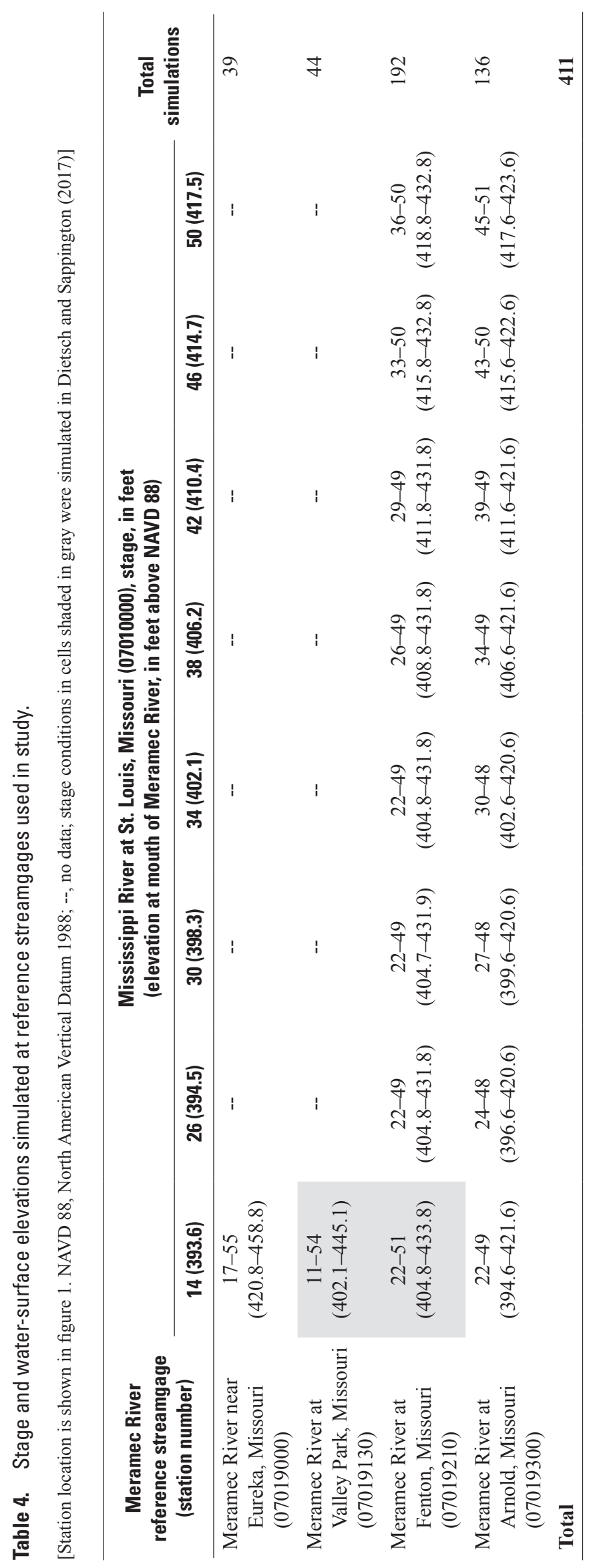

elevations of $404.8 \mathrm{ft}$ and $433.8 \mathrm{ft}$ above NAVD 88 , respectively. Water-surface profiles were generated for a total of 136 Mississippi River and Meramec River stage conditions at 1 - $\mathrm{ft}$ intervals ranging from $22 \mathrm{ft}$ to $51 \mathrm{ft}$ as referenced to the local streamgage datum for the Arnold reach (which includes USGS station 07019300), and these stages correspond to elevations of $394.6 \mathrm{ft}$ and $423.6 \mathrm{ft}$ above NAVD 88, respectively. A flow hydrograph was used as the upstream boundary condition for the HEC-RAS model. A trial and error process was used to determine the proper model inputs to simulate water-surface profiles relating to each 1-ft mapped stage at stations $07019000,07019130,07019210$, and 07019300 to relate the boundary condition to the target stages at the streamgages. Because downstream constant-stage Mississippi River conditions varied, the maximum upstream boundary condition flows resulted in variable maximum stages for each set of watersurface profiles (table 4).

\section{Development of Flood-Inundation Maps}

Flood-inundation maps were created in a GIS for the water-surface profiles by combining the profiles and DEM data. The DEM data were derived from the same lidar data described previously in the "Topographic and Bathymetric Data" section and, therefore, have an estimated vertical accuracy of $2 \mathrm{ft}$ (that is, plus or minus $1 \mathrm{ft}$ ). Estimated flood-inundation boundaries for each simulated profile were developed with HEC-GeoRAS software (Ackerman, 2009), which prepares geometric data for import into HEC-RAS and processes simulation results exported from HEC-RAS (Brunner, 2010). Shapefile polygons and depth grids of the inundated areas for each profile were modified, as required, in the ArcMap application of ArcGIS (Esri, 2017) to ensure a hydraulically reasonable transition of the flood boundaries between modeled cross sections. Although the water-surface profiles extended throughout the combined 37.2-mi reach, shapefile polygons and depth grids associated with the watersurface profiles for station 07019000 were clipped to the limits of the Eureka reach. Similarly, shapefile polygons and depth grids associated with the water-surface profiles were clipped to the limits of the Valley Park reach for station 07019130, were clipped to the limits of the Fenton reach for station 07019210, and were clipped to the limits of the Arnold reach for station 07019300. Any inundated areas that were detached from the main channel were examined to identify subsurface connections with the main river, such as through culverts under roadways. Where such connections existed, the mapped inundated areas were retained in their respective flood maps; otherwise, the erroneously delineated parts of the flood extent were deleted. The flood-inundation areas are overlaid on high-resolution, georeferenced aerial photographs of the study reaches (U.S. Department of Agriculture, 2014). Bridge surfaces are shown as not inundated until the lowest flood stage that either intersects the lowest structural chord of the bridge or completely inundates one or both approaches to the bridge. 
In these latter circumstances, the bridge surface is depicted as being inundated. Estimates of water depth can be obtained from the depth-grid data that are included with the flood maps on an interactive USGS mapping application described in the "Flood-Inundation Map Delivery" section. Data generated during this study (depth grids and shapefiles) are available through a USGS data release at https://doi.org/10.5066/ P9B0XLJL (Dietsch and Strauch, 2018).

\section{Flood-Inundation Map Delivery}

The current study documentation is available online at the USGS Publications Warehouse (https://doi.org/10.5066/ P9B0XLJL), which presents the current stage at the cooperative USGS stations 07019000, 07019130, 07019210, 07019300 to which the inundation maps are referenced. A second link connects to the NWS AHPS website (National Weather Service, 2018a) so the user can obtain applicable information on forecasted peak stages. The estimated floodinundation maps contain sufficient detail so that preparations for flooding and decisions for emergency response can be completed efficiently. Bridge surfaces are not shaded - that is, shown as not inundated - until the lowest flood stage that either intersects the lowest structural chord of the bridge or completely inundates one or both approaches to the bridge. In these latter circumstances, the bridge surface is depicted as being shaded. A shaded building should not be interpreted to mean that the structure is completely submerged; rather, bare earth surfaces near the building are inundated. The water depth (as indicated in the mapping application by holding the cursor over an inundated area) near the building would be an estimate of the water level inside the structure, unless flood-proofing measures had been implemented.

\section{Disclaimer for Flood-Inundation Maps}

The flood-inundation maps should not be used for navigation or regulatory, permitting, or other legal purposes. The USGS provides these maps "as is" for a quick reference, emergency planning tool but assumes no legal liability or responsibility resulting from the use of this information.

\section{Uncertainties and Limitations Regarding Use of Flood-Inundation Maps}

Although the flood-inundation maps represent the boundaries of inundated areas with a distinct line, some uncertainty is associated with these maps. The flood boundaries shown were estimated based on water stages and discharges at selected USGS streamgages. Water-surface elevations along the stream reaches were estimated by unsteady-state hydraulic modeling, assuming unobstructed flow, and using discharges and hydrologic conditions anticipated at the USGS streamgage(s). The hydraulic model reflects the land-cover characteristics and any bridge, dam, levee, or other hydraulic structures existing as of December 2015. Unique meteorological factors (timing and distribution of precipitation) may cause actual discharges along the modeled reach to differ from those assumed during a flood, which may lead to deviations in the water-surface elevations and inundation boundaries shown. Additional areas may be flooded because of unanticipated conditions such as changes in the streambed elevation or roughness, backwater into major tributaries along a main stem river, or backwater from localized debris or ice jams. The accuracy of the floodwater extent portrayed on these maps will vary with the accuracy of the DEM used to simulate the land surface.

If this series of flood-inundation maps will be used in conjunction with NWS river forecasts, the user should be aware of additional uncertainties that may be inherent or factored into the NWS forecast procedures. The NWS uses forecast models to estimate the quantity and timing of water flowing through selected stream reaches in the United States. These forecast models (1) estimate the amount of runoff generated by precipitation and snowmelt, (2) simulate the movement of floodwater as it proceeds downstream, and (3) predict the flow and stage (and water-surface elevation) for the stream at a given location (AHPS forecast point) throughout the forecast period (every 6 hours and 3 to 5 days out in many locations). For more information on AHPS forecasts, please see https://water.weather.gov/ahps/pcpn_and_river_forecasting.pdf.

Another source of uncertainty relevant to the study reach is the Valley Park levee system, which, if breached, can produce variable flood extents and water depths on the landward side of the levee. Additional uncertainties and limitations pertinent to this study may be described elsewhere in this report.

\section{Summary}

Digital flood-inundation maps were developed by the U.S. Geological Survey (USGS) in cooperation with the U.S. Army Corps of Engineers, Metropolitan St. Louis Sewer District, Missouri Department of Transportation, Missouri American Water, Federal Emergency Management Agency Region 7, and the cities of Pacific, Eureka, Wildwood, and Arnold and referenced to the Meramec River near Eureka, Missouri; the Meramec River at Valley Park, Mo.; the Meramec River at Fenton, Mo.; and the Meramec River at Arnold, Mo., streamgages. The maps cover a 37.2-mile (mi) long reach extending upstream from Eureka, Mo., to near the confluence of the Meramec and Mississippi Rivers. The reach at the Meramec River near Eureka, Mo., is $11.0 \mathrm{mi}$; the reach at the Meramec River at Valley Park, Mo., is $9.1 \mathrm{mi}$; the reach at the Meramec River at Fenton, Mo., is $7.6 \mathrm{mi}$; and the reach at the Meramec River at Arnold, Mo., is $9.5 \mathrm{mi}$. The maps were developed using the U.S. Army Corps of Engineers Hydrologic Engineering Centers River Analysis System program to compute water-surface profiles and to delineate estimated 
flood-inundation areas and depths of flooding for selected stream stages. The Hydrologic Engineering Centers River Analysis System hydraulic model was calibrated to a stagedischarge rating at the Meramec River near Eureka, Mo., streamgage and to high-water marks from the December 2015January 2016 flood. The model was used to compute watersurface profiles for 1-foot stage intervals referenced to the local streamgage datum at the Meramec River near Eureka, Mo.; the Meramec River at Valley Park, Mo.; the Meramec River at Fenton, Mo.; and the Meramec River at Arnold, Mo., streamgages. The simulated stages of each set of profiles ranged from the National Weather Service action stage (about bankfull flow) to the stage corresponding to the estimated 0.2-percent annual exceedance probability (500-year recurrence interval) flood at the Meramec River near Eureka, Mo., streamgage. The conditions used for the hydraulic simulations included 1 scenario in which the Mississippi River was assumed be at or near the stage corresponding to the median annual flow and 7 conditions in which the Mississippi River stage was near or above the National Weather Service "action stage." The simulated water-surface profiles then were combined with a geographic information system digital elevation model derived from light detection and ranging data to delineate estimated floodinundation areas as shapefile polygons and depth grids for each profile. These flood-inundation polygons were overlaid on high-resolution, georeferenced aerial photographs of the study reaches. The flood maps are available through a mapping application that can be accessed on the USGS Flood Inundation Mapping Science website (https://water.usgs.gov/osw/ flood_inundation).

The interactive maps on this mapping application can give users a general indication of depth of water at any point by clicking within the shaded areas using the mouse cursor. These maps, in conjunction with the real-time stage data from the cooperative USGS streamgages - the Meramec River near Eureka, Mo. (USGS station 07019000), the Meramec River at Valley Park, Mo. (USGS station 07019130), the Meramec River at Fenton, Mo. (USGS station 07019210), and the Meramec River at Arnold, Mo. (USGS station 07019300), - and forecasted flood stage data from the National Weather Service Advanced Hydrologic Prediction Service, will help to guide the general public in taking individual safety precautions and will provide emergency management personnel with a tool to efficiently manage emergency flood operations and postflood recovery efforts.

\section{References Cited}

Ackerman, C.T., 2009, HEC-GeoRAS, GIS tools for support of HEC-RAS using ArcGIS, user's manual, version 4.2: Davis, Calif., U.S. Army Corps of Engineers, Hydrologic Engineering Center [variously paged].
Arcement, G.J., and Schneider, V.R., 1989, Guide for selecting Manning's roughness coefficients for natural channels and flood plains: U.S. Geological Survey Water-Supply Paper 2339,38 p.

Barnes, H.H., Jr., 1967, Roughness characteristics of natural channels: U.S. Geological Survey Water-Supply Paper 1849, 213 p. [Also available at https://pubs.usgs.gov/wsp/ wsp_1849/pdf/wsp_1849.pdf.]

Brunner, G.W., 2010, HEC-RAS River Analysis System, hydraulic reference manual, version 4.1: Davis, Calif., U.S. Army Corps of Engineers, Hydrologic Engineering Center [variously paged].

Brunner, G.W., 2016, HEC-RAS River Analysis System, hydraulic reference manual, version 5.0: Davis, Calif., U.S. Army Corps of Engineers, Hydrologic Engineering Center [variously paged].

Coon, W.F., 1998, Estimation of roughness coefficients for natural stream channels with vegetated banks: U.S. Geological Survey Water-Supply Paper 2441, 133 p. [Also available at https://pubs.usgs.gov/wsp/2441/report.pdf.]

Dewberry, 2012, National Enhanced Elevation Assessment: Fairfax, Va., Dewberry, 84 p., accessed April 5, 2017, at http://www.dewberry.com/docs/default-source/documents/ neea_final-report_revised-3-29-12.pdf?sfvrsn $=0$.

Dietsch, B.J., and Sappington, J.N., 2017, Flood-inundation maps for the Meramec River at Valley Park and at Fenton, Missouri, 2017: U.S. Geological Survey Scientific Investigations Report 2017-5116, 12 p. [Also available at https:// doi.org/10.3133/sir20175116.]

Dietsch, B.J., and Strauch K.R., 2018, Flood-Inundation Maps of the Meramec River from Eureka to Arnold, Missouri, 2018: U.S. Geological Survey data release, https://doi.org/10.5066/P9B0XLJL.

Esri, 2017, ArcGIS: Esri web page, accessed February 6, 2017, at https://www.esri.com/software/arcgis/.

Federal Emergency Management Agency, 2015, Flood insurance study, St. Louis County, Missouri, and incorporated areas: Washington, D.C., Federal Emergency Management Agency, 202 p.

Holmes, R.R., Jr., Koenig, T.A., Rydlund, P.H., Jr., and Heimann, D.C., 2016, Examination of flood characteristics at selected streamgages in the Meramec River Basin, eastern Missouri, December 2015-January 2016: U.S. Geological Survey Open-File Report 2016-1140, 7 p., accessed March 28, 2017, at https://doi.org/10.3133/ofr20161140.

King, H.W., and Brater, E.F., 1963, Handbook of hydraulics (5th ed.): New York, McGraw Hill Book Company, 1373 p. 
Missouri Department of Natural Resources, 2015, The state of our Missouri waters, Meramec River watershed: Missouri Department of Natural Resources web page, accessed April 6, 2017, at https://dnr.mo.gov/env/docs/2015MeramecWater shedSummary.pdf.

National Weather Service, 2018a, Advanced Hydrologic Prediction Service: National Weather Service web page, accessed March 28, 2018, at https:/water.weather.gov/ahps/ forecasts.php.

National Weather Service, 2018b, National Weather Service Glossary: National Weather Service web page, accessed March 28, 2018, at https://w1.weather.gov/glossary/index. php? word=Flood + Categories.

Omernik, J.M., 1987, Ecoregions of the conterminous United States: Annals of the Association of American Geographers, v. 77 , no. 1 , p. 118-125, scale 1:7,500,000.

Surdex Corporation, 2012a, Missouri Counties Lidar Project-April 20, 2012: Lidar Acquisition and Processing Report, accessed March 9, 2017, at ftp://lidar.wustl.edu/ StLouis2012/Project\%20Data/Reports/LiDAR\%20Acquistition-Processing\%20Summary\%20St\%20Louis.pdf.

Surdex Corporation, 2012b, Missouri Counties Lidar Project-May 1, 2012: Lidar Accuracy Report, accessed March 9, 2017, at ftp://lidar.wustl.edu/StLouis2012/Project $\% 20$ Data/Reports/LiDAR\%20Accuracy\%20Report\%20St $\% 20$ Louis.pdf.
U.S. Army Corps of Engineers, 2004, Upper Mississippi River System Flow Frequency Study: U.S. Army Corps of Engineers web page, accessed March 28, 2018, at http://www. mvr.usace.army.mil/Missions/Flood-Risk-Management/ Upper-Mississippi-Flow-Frequency-Study/.

U.S. Army Corps of Engineers, 2017, National Levee Database: U.S. Army Corps of Engineers web page, accessed March 9, 2017, at http://nld.usace.army.mil/egis/ $\mathrm{f?p}=471: 1: 0: \mathrm{NO}$.

U.S. Census Bureau, 2010, 2010 census interactive population search-Missouri: U.S. Census Bureau web page, accessed March 2017 at https:/www.census.gov/data/datasets/2017/ demo/popest/counties-total.html.

U.S. Department of Agriculture, 2014, Status maps: U.S. Department of Agriculture web page, accessed April 10, 2018, at https://www.fsa.usda.gov/programs-and-services/ aerial-photography/status-maps/index.

U.S. Geological Survey, 2017a, USGS Flood Inundation Mapping Program: U.S. Geological Survey web page, accessed February 6, 2017, at https://water.usgs.gov/osw/flood_inundation.

U.S. Geological Survey, 2017b, USGS water data for the Nation: U.S. Geological Survey National Water Information System database, accessed February 6, 2017, at https://doi. org/10.5066/F7P55KJN.
For more information about this publication, contact:

Director, USGS Central Midwest Water Science Center

1400 Independence Road

Rolla, MO 65401

573-308-3667

For additional information, visit:

https://www.usgs.gov/centers/cm-water

Publishing support provided by the

Rolla Publishing Service Center 

